\title{
"Our Militancy is in Our Openness": Gay Employment Rights Activism in California and the Question of Sexual Orientation in Sex Equality Law - ERRATUM
}

\author{
K. TURK
}

doi:10.1017/S0738248013000072, Published by Cambridge University Press, 7 May 2013.

In the article "'Our Militancy is in Our Openness": Gay Employment Rights Activism in California and the Question of Sexual Orientation in Sex Equality Law" "1 there was an error introduced. On page 2, the first sentence should read: "Despite the protest's religious intensity..." The publisher regrets this error.

\section{Reference}

1. Turk, K. (2013) “"Our Militancy is in Our Openness": Gay Employment Rights Activism in California and the Question of Sexual Orientation in Sex Equality Law." Law and History Review, 31 (2013), 423-469. doi:10.1017/S0738248013000072. 